\title{
NILAI - NILAI ANTI KORUPSI DALAM PEMBELAJARAN AKUNTANSI SEBAGAI PENGEMBANGAN KARAKTER SISWA DI SMK
}

\author{
${ }^{1)}$ Siswanto, ${ }^{2)}$ Suyanto, ${ }^{3)}$ Badrun Kartowagiran \\ ${ }^{1,2)}$ FE Universitas Negeri Yogyakarta, ${ }^{3)}$ FT Universitas Ngeri Yoyakarta \\ siswanto@uny.ac.id, suyan@ymail.com, kartowagiran@uny.ac.id
}

\begin{abstract}
Abstrak
Penelitian ini bertujuan untuk mendiskripsikan: (1) faktor Kualitas Rencana Pelaksanaan Pembelajaran (RPP), Kompetensi Guru, Persepsi guru terhadap kepemimpinan kepala sekolah dan Persepsi guru terhadap kultur sekolah dalam mengintegrasikan nilai-nilai anti korupsi sebagai pengembangan karakter siswa; (2) pengaruh berbagai faktor terhadap kualitas pembelajaran Akuntansi yang mengintegrasikan nilai-nilai anti korupsi, dan ; (3) mengetahui faktor yang paling berpengaruh terhadap pembelajaran Akuntansi yang mengintegrasikan nilai-nilai anti korupsi. Populasi dalam Penelitian ini adalah 279 Guru Akuntansi SMK Bisnis dan Manajemen di Daerah Istimewa Yogyakarta terdistribusi pada 59 SMK. Sampel penelitian diambil 165 guru dan 200 siswa diambil dengan proposional purposive sampling. Data dianalisis dengan teknik statistik deskriptif dan inferensial. Statistik deskriptif digunakan untuk menjelaskan rata-rata skor kualitas setiap faktor dan statistik inferensial dengan SEM untuk menguji hipotesis. Uji kecocokan model dengan Structural Equation Modeling (SEM) dengan bantuan program LISREL 8.80. Hasil penelitian menunjukkan :(1) Rencana Pelaksanaan Pembelajaran (RPP) telah mengitegrasikan nilai-nilai anti korupsi dengan baik, siswa memberi penilaian sangat baik pada kompetensi guru, guru memiliki persepsi baik terhadap kepemimpinan kepala sekolah, guru memiliki persepsi baik terhadap kultur sekolah; (2) ada pengaruh yang signifikan dari berbagai faktor terhadap pembelajaran Akuntansi yang mengintegrasikan nilai-nilai anti korupsi. (3) kualitas Rencana Pembelajaran adalah faktor yang paling berpengaruh terhadap kualitas Pembelajaran Akuntansi.
\end{abstract}

Kata kunci: integrasi nilai-nilai anti korupsi, pembelajaran akuntansi, pengembangan karakter siswa

\section{ANTI-CORRUPTION VALUES INTO ACCOUNTING LEARNING TO BUILD STUDENTS' CHARACTERS AT VOCATIONAL HIGH SCHOOLS (VHSS)}

\author{
Siswanto, Suyanto, Badrun Kartowagiran \\ Pendidikan Akuntansi FE UNY, Pascasarjan UNY, Pascasarjana UNY \\ siswanto@uny.ac.id, suyan@ymail.com, kartowagiran@uny.ac.id
}

\begin{abstract}
This study aims to: (1) describe the factors of the lesson plan quality, teachers' competencies, teachers' perceptions of principals' leadership, and teachers' perceptions of the school culture in integrating anti-corruption values to build students' characters; (2) describe the effects of a variety of factors on the quality of Accounting learning that integrates anti-corruption values; and (3) find out the factor with the greatest effect on Accounting learning that integrates anti-corruption values. The research population comprised 279 Accounting teachers at 59 Business and Management VHSs in Yogyakarta Special Region. The research sample, consisting of 165 teachers and 200 students, was selected by means of the proportional purposive sampling technique. The data were analyzed using descriptive and inferential statistics. The descriptive statistics were used to explain the mean score of the quality of each factor and the inferential statistics with Structural Equation Modeling (SEM) were used to test the hypotheses. The model fit test used SEM processed by the LISREL 8.80 program. The results of the study are as follows. (1) the lesson plans have integrated anti-corruption values well, the students give excellent ratings to the teachers' competencies, the teachers have good perceptions of the principals' leadership, and the teachers have good perceptions of the school culture. (2) there are significant effects of a variety of factors on Accounting learning that integrates anti-corruption values. (3) the quality of the lesson plans is the factor with the greatest effect on the quality of Accounting learning.
\end{abstract}

Keywords: integration of anti-corruption values, accounting learning, students' character building 


\section{PENDAHULUAN}

Setiap hari di berbagai media masyarakat disuguhi dengan berbagai informasi perilaku korupsi yang merugikan keuangan negara. Meningkatnya kasus korupsi di negeri ini dapat dilihat dari data penanganan perkara tindak pidana korupsi oleh Komisi Pemberantasan Korupsi (KPK) dari tahun 20042014: penyelidikan 596 perkara, penyidikan 363 perkara, penuntutan 287 perkara, inkracht 243 perkara, dan eksekusi 252 perkara. Data terakhir yang di publikasikan oleh Indonesia Corrupsion Watch (ICW) sampai awal 2015 jumlah kasus melonjak menjadi 2.433, dari jumlah itu 536 proses penyidikan oleh Kepolisian, 1.775 oleh Kejaksaan dan 122 oleh KPK (Komisi Pemberantasan Korupsi, 2014)

Pendidikan dapat dijadikan media untuk melakukan pencegahan awal korupsi melalui penanaman nilai-nilai karakter anti korupsi sejak dini. Dengan penanaman nilainilai ini dimaksudkan menjadi gerakan preventif timbulnya mental korupsi pada generasi bangsa. Upaya pencegahan tindakan korupsi tidak hanya dilakukan pada satu generasi saja, melainkan secara terus menerus dan berkelanjutan. Pendidikan anti korupsi sejak dini bisa menjadi harapan untuk menciptakan generasi yang bersih dari korupsi. Penanaman nilainilai anti korupsi bisa dimulai dari kalangan siswa sekolah dasar hingga yang berusia sekolah menengah atas (SMA) dan perguruan tinggi.

Peran Pendidikan dalam pencegahan tindak korupsi sangat tepat diintegrasikan dalam domain kognitif (pengetahuan) afektif (sikap) dan psikomotor (keterampilan). Pengintegrasian nilai-nilai karakter anti korupsi sangat tepat bila diintegrasikan dalam setiap mata pelajaran yang sudah ada sejalan dengan wajibnya setiap pembelajaran untuk mengintegrasikan Pendidikan Karakter.

Dalam kamus, Purwadarminta mendefinisikan karakter diartikan sebagai tabiat, watak, sifat-sifat kejiwaan, akhlak atau budi pekerti yang membedakan seseorang dari orang lain (Poerwadarminta, 1999, p. 396). Dari pengertian tersebut membangun karakter (Character Building) adalah proses mengukir atau memahami jiwa, sehingga berbentuk unik, menarik, dan berbeda atau dapat dibedakan dengan orang lain. Moralitas harus mendasari dalam setiap pembelajaran yang dilakukan,
Durkheim (1961, p. 23) menegaskan tiga komponen dasar moralitas, yaitu: disiplin atau kewajiban, memasyarakat dan otonomi diri. Oleh sebab itu komponen-komponen tersebut harus menjadi acuan dalam setiap kegiatan pembelajaran yang dikembangkan sekolah. Asumsi tersebut dapat dijadikan pijakan landasan filosifis dalam perencanaan pembelajaran di sekolah.

Sesuai dengan undang-undang No. 20 tahun 2003 tentang Sistem Pendidikan Nasional (Bab 2 Pasal 3) (Depdiknas, 2003) diamanatkan pendidikan karakter melalui berbagai proses pendidikan, hal ini dipertegas dengan Instruksi Presiden Republik Indonesia Nomor 1 Tahun 2010 tentang Percepatan Pelaksanaan Prioritas Pembangunan Nasional Tahun 2010 (Presiden Republik Indonesia, 2010) yang mengamanatkan program penguatan metodologi dan kurikulum dengan cara menyempurnakan kurikulum dan metode pembelajaran aktif berdasarkan nilai-nilai budaya bangsa untuk membentuk daya saing dan karakter bangsa.

Kementerian Pendidikan Nasional (Kemendiknas) dan Komisi Pemberantasan Korupsi (KPK) sejak tahun 2011 telah memulai menerapkan Pendidikan Antikorupsi dalam kurikulum prasekolah, SD/MI, SMP/MTs, SMA/MA, SMK, dan perguruan tinggi. Pendidikan antikorupsi diharapkan tidak hanya menjadi sebuah transformasi konseptual yang tidak membumi. Sejalan dengan itu pendidikan karakter pun diharapkan dapat dikolaborasikan untuk melaksanakan pendidikan anti korupsi sebagai bagian pengembangan karakter generasi kita. Implementasi kebijakan ini adalah bagaimana mengintegrasikan pendidikan karakter Bangsa dalam pembelajaran.

Pembelajaran Akuntansi merupakan kompetensi yang ada di SMK Bisnis dan Manajemen yang menyiapkan siswa untuk memiliki kompetensi melakukan kegiatan pencatatan keuangan di perusahaan jasa dan dagang maupun manufaktur. Pembelajaran Akuntansi di SMK sebagai salah satu kegiatan pembelajaran diharapkan dapat dijadikan media untuk mengebangan karakter anti korupsi, pembelajaran akuntansi bukan pendidikan bebas nilail, melainkan pendidikan yang harus mendasarkan pada pendidikan karakter/moral siswa dengan mengitegrasikan nilai-nilai luhur dalam setiap aktivitas pembelajaran yang dilaksanakan. 
Sekolah diharapkan dapat melakukan berbagai aktivitas untuk mengawal seluruh kegiatan pembelajaran agar dapat senantiasa masukan nilai-nilai anti korupsi dalam setiap pembelajaran yang dilakukan. Sekolah diharapkan dapat menciptakan manajemen pembelajaran yang mengembangkan karakter anti korupsi siswa, penanaman nilai-nilai anti korupsi merupakan upaya memahami aspekaspek yang terdapat dalam diri manusia untuk diarahkan, dibina dan dikembangkan agar selaras dengan standar moral yang berlaku dan sesuai dengan lingkungan kerja dan masyarakat pada umumnya.

Untuk dapat mengoptimalkan kegiatan pembelajaran Akuntansi yang mengintegrasikan nilai-nilai anti korupsi diperlukan kajian kuantitatif empiris bagaimana kontribusi variabel-variabel yang menopang pembelajaran. Proses pembelajaran Akuntansi yang meingintegrasikan nilai-nilai anti korupsi secara dominan dipengarui oleh guru, rencana pembelajaran, kepemimpinan kepala sekola dan kultur sekolah, keempat elemen tersebut di prediksi memberikan pengaruh dan kontribusi yang dominan dalam proses pembelajaran. Penelitian ini secara umum bertujuan untuk menentukan koefisien pengaruh faktor-faktor determinan yang terkait dengan proses pembelajaran Pendidikan Akuntansi di kelas dalam pengembangan karakter anti korupsi.

Dharma (2003) tujuan pendidikan anti korupsi adalah: (1) pembentukan pengetahuan dan pemahaman mengenai bentuk korupsi dan aspek-aspeknya; (2) pengubahan persepsi dan sikap terhadap korupsi; dan (3) pembentukan keterampilan dan kecakapan baru yang ditujukan untuk melawan korupsi.

Komisi Pemberantasan Korupsi (KPK) telah merumuskan ada sembilan nilai dasar yang perlu ditanamkan dan diperkuat melalui pelaksanaan pendidikan antikorupsi di sekolah, yaitu nilai kejujuran, adil, berani, hidup sederhana, tanggung jawab, disiplin, kerja keras, hemat dan mandiri. Hasil penelitian Unger dan Crowford, menemukan bahwa salah satu lingkungan anak-anak yang berpengaruh besar bagi pembentukan karakter dalam diri anak-anak adalah cerita-cerita dan komunikasi pesan-pesan national chararacter building yang diperoleh di lingkungan keluarga, teman bermain, sekolah, dan bacaan-bacaan (Sunarto, 2000, p. 158).
Penanaman karakter pada para peserta didik merupakan proses penyesuaian kepribadian yang perlu memperhatikan bermacam-macam prinsip dasar pertumbuhan. Satmoko (1983, p. 216) menegaskan bahwa mekanisme penyesuaian tersebut pada dasarnya merupakan sebagian dari usaha kependidikan yang dilakukan oleh keluarga, sekolah, maupun masyarakat, serta berlangsung seumur hidup. Itulah sebabnya, perencanaan pembelajaran yang praktis, aplikabel, dan memperhatikan perkembangan dan pertumbuhan peserta didik sangat diperlukan, dalam upaya pembelajaran nilai yang membawa muatan pembangunan karakter.

Selanjutnya dalam memberikan gambaran lebih lanjut mengenai karakter, Cronbach (1977, p. 57) menguraikan sebagai berikut.

"Character is not acumulation of separate habits and ideas. Character is an aspect of the personality. Beliefs, feelings, and actions, are linked; to change character is to reorganize the personality. Tiny lessons on principles of good conduct will not be effective if they cannot be integrated with the person's sistem of beliefs about in self, about others, and about the good community".

Berbeda dengan Cronbach, adalah Lickona (2003, p. 37) yang memandang karakter terbagi ke dalam tiga bidang yang saling terkait yakni moral knowing, moral feeling, dan moral behavior. Oleh karena itu, karakter yang baik mengandung tiga kompetensi, yakni mengetahui hal yang baik, ada keinginan terhadap hal yang baik, dan melakukan hal yang baik sehingga pada gilirannya ia akan menjadi kebiasaan berpikir, kebiasaan hati, dan kebiasaan bertindak.

Perencanaan pembelajaran merupakan dasar/acuan dalam melaksanakan kegiatan pembelajaran, sehingga perencanaan pembelajaran merupakan hal yang amat penting dalam konteks proses pembelajaran. Kemp (1994, pp. 13-15) dalam merancang perencanaan pembelajaran ada unsur-unsur yang harus diperhatikan, yaitu : (1) memperkirakan kebutuhan belajar untuk merancang suatu program pembelajaran dengan menyatakan tujuan, kendala dan prioritas yang harus diketahui; (2) memilih pokok bahasan atau 
tugas untuk dilaksanakan dan menunjukkan tujuan yang ingin dicapai; (3) meneliti ciri siswa yang harus mendapat perhatian selama perencanaan; (4) menentukan isi pelajaran dan menguraikan unsur tugas yang berkaitan dengan tujuan; (5) menyatakan tujuan belajar yang ingin dicapai dari segi isi dan unsur tugas; (6) merancang kegiatan belajar mengajar untuk mencapai tujuan yang sudah dinyatakan; (7) memilih sejumlah media untuk mendukung kegiatan pengajaran;(8) merincikan pelayanan penunjang yang diperlukan untuk mengembangkan dan melaksanakan semua kegiatan serta untuk memperoleh atau membuat bahan; (9) mempersiapkan evaluasi hasil belajar dan hasil program; (10) menentukan persiapan siswa untuk mempelajari pokok bahasan dengan memberikan uji awal kepada mereka.

Suhertian, (1990, p. 69) mengatakan kompetensi adalah pemilikan, penguasaan, keterampilan dan kemampuan yang dituntut jabatan seseorang. Oleh sebab itu seorang calon guru agar menguasai kompetensi guru dengan mengikuti pendidikan khusus yang diselenggarakan oleh LPTK. Menurut PP RI No. 19/ 2005 tentang Standar Nasional Pendidikan (Menteri Pendidikan Nasional, 2005) Pasal 28 , pendidik (guru) adalah agen pembelajaran yang harus memiliki empat jenis kompetensi, yakni kompetensi pedagogik, kepribadian, profesional, dan sosial. (Kusnandar, 2008, p. 17) menyatakan kompetensi guru adalah seperangkat penguasaan kemampuan yang harus ada dalam diri guru agar dapat mewujudkan kinerjanya secara tepat dan efektif.

Mulyasa (2002, p. 19) mendefinisikan kepemimpinan Kepala sekolah sebagai kemampuan untuk mengggerakkan, mempengaruhi, memotivasi, mengajak, mengarahkan, menasehati, membimbing, menyuruh, memerintah, melarang dam bahkan menghukum (kalau perlu), serta membina agar manusia sebagai media mamajemen mau bekerja dalam rangka mencapai tujuan administrasi secara efektif dan efisien. Purwanto (2003, p. 24) menjelaskan bahwa kepemimpinan merupakan suatu bentuk persuasi, suatu seni pembinaan kelompok orang-orang tertentu, biasanya melalui human relation dan motivasi sehingga mereka tanpa adanya rasa takut mau bekerja sama dan membanting tulang untuk mencapai segala apa yang menjadi tujuan organisasi.
Salah satu faktor penting dalam upaya pembangunan karakter anti korupsi adalah pada proses pembelajaran adalah kultur sekolah. Hal ini terkait dengan tiga pilar penting dalam peningkatan kualitas sekolah yaitu proses belajar mengajar, kepemimpinan dan manajemen sekolah, serta kultur sekolah (Menteri Pendidikan Nasional, 2006, p. 47). Kultur sekolah ialah a complex set of beliefs, values and traditions, ways of thinking and behaving yang membedakannya dari institusiinstitusi lainnya.

Berdasarkan uraian yang telah disampaikan tersebut, penelitian ini bertujuan untuk mendiskripsikan: (1) faktor kualitas Rencana Pelaksanaan Pembelajaran (RPP), Kompetensi Guru, Persepsi guru terhadap kepemimpinan kepala sekolah dan Persepsi guru terhadap kultur sekolah dalam mengintegrasikan nilainilai anti korupsi sebagai pengembangan karakter siswa.; (2) pengaruh berbagai faktor terhadap kualitas pembelajaran Akuntansi yang mengintegrasikan nilai-nilai anti korupsi, dan; (3) mengetahui faktor yang paling berpengaruh terhadap pembelajaran Akuntansi yang mengintegrasikan nilai-nilai anti korupsi.

\section{METODE}

Penelitian ini dikategorikan dalam enelitian exspost facto dengan menggunakan pendekatan kuantitatif non eksperimen. Penelitian ini mengunakan model analisis faktor konfirmatori (confirmatory factor analysis) dan STRUCTURAL EQUATION MODELING (SEM), analisis faktor konfirmatori didasarkan pada premis bahwa masing masing variabel manifest atau variabel yang dapat diamati secara sendiri tidak dapat menggambarkan secara sempurna suatu konsep atau suatu variabel laten atau variabel konstruk (Kartowagiran, 2008, p. 184).

Penelitian dilaksanakan di Daerah Istimewa Yogyakarta. Populasi dalam Penelitian ini adalah Guru Akuntansi SMK Bisnis dan Manajemen di Daerah Istimewa Yogyakarta sejumlah 279 guru. Berdasarkan perhitungan sampel diambil 165 dan 200 siswa diambil dengan Proposional Purposive sampling.

Data dikumpulkan dengan angket (kuesioner), lembar observasi dan dokumentasi. Validitas isi (content validity) untuk kuesioner, lembar observasi dan lembar telaah 
RPP dilakukan dengan expert judgement dan formula Aiken's $V$. Validasi konstruk kuesioner dilakukan dengan analisis Exploratory factor analysis (EFA) dilanjutkan Confirmatory factor analysis (CFA), reliabilitas kuesioner diestimasi dengan formula Alpha Cronbach dan lembar observasi dengan Intra Class Correlation (ICC). Data dianalisis dengan teknik statistik deskriptif dan inferensial. Statistik deskriptif digunakan untuk menjelaskan rata-rata skor kualitas masing-masing faktor dan statistik inferensial dengan SEM untuk menguji hipotesis. Uji kecocokan model dengan Structural Equation Modeling (SEM) dengan bantuan program LISREL 8.80.

Dalam analisis ini dilakukan dua tahap, yaitu sebagai berikut; (1) menguji kebenaran model dengan melihat apakah terdapat perbedaan signifikan antara model dengan data (model fit), dan (2) jika ada kesesuaian antara teori dengan data, maka dapat dilakukan pengujian atau hipotesis, tentang hubungan struktural dalam model tersebut (koefisien regresi dalam skala/true score).

Dalam analisis ini dilakukan dua tahap, yaitu sebagai berikut; (1) menguji kebenaran model dengan melihat apakah terdapat perbedaan signifikan antara model dengan data (model fit), dan (2) jika ada kesesuaian antara teori dengan data, maka dapat dilakukan pengujian atau hipotesis, tentang hubungan struktural dalam model tersebut (koefisien regresi dalam skala/true score).

Dalam penelitian ini model yang diuji adalah teori yang menyatakan bahwa Rencana Pembelajaran, Kompentensi Guru, Kepemimpinan Kepala Sekolah, dan kultur Sekolah merupakan faktor-faktor determinan dari pengitegrasian Pendidikan anti korupsi dalam Pembelajaran Akuntansi sebagai pengembangan Karakter. GFI (goodness of fitindexs) merupakan ukuran mengenai ketepatan model teoritis dalam menghasilkan observed matriks kovarians. Nilai Chi-square yang kecil ini berkisar antara 0 dan 1 . Nilai GFI yang lebih besar daripada 0,9 menunjukan fit berarti suatu model yang baik. Uji model fit diperoleh melalui pengujian hipotesis tentang model yaitu koefisien korelasi dengan menggunakan beberapa persamaan

Dalam penelitian ini model yang diuji adalah teori yang menyatakan bahwa Rencana Pembelajaran, Kompentensi Guru, Kepemimpinan Kepala Sekolah, dan kultur Sekolah merupakan faktor-faktor determinan dari pengitegrasian Pendidikan anti korupsi dalam Pembelajaran Akuntansi sebagai pengembangan Karakter. GFI (goodness of fitindexs) merupakan ukuran mengenai ketepatan model teoritis dalam menghasilkan observed matriks kovarians. Nilai Chi-square yang kecil ini berkisar antara 0 dan 1 . Nilai GFI yang lebih besar daripada 0,9 menunjukan fit berarti suatu model yang baik. Uji model fit diperoleh melalui pengujian hipotesis tentang model yaitu koefisien korelasi dengan menggunakan beberapa persamaan.

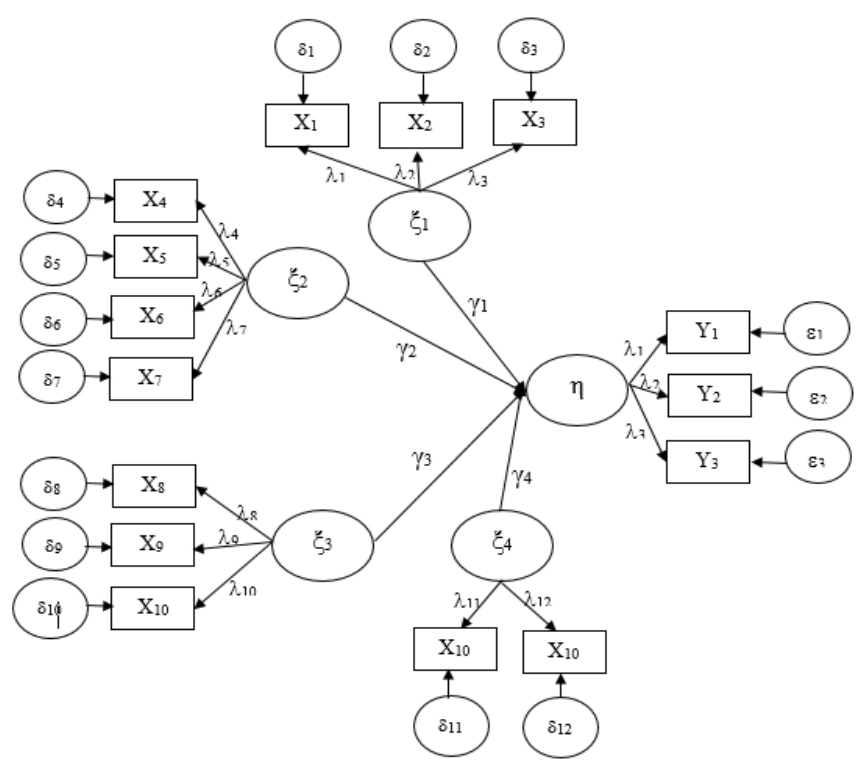

Gambar 1. Hubungan Fungsional antar Variabel

Modifikasi model akan dilakukan melalui konstruksi ulang untuk mendapatkan model yang paling dekat dengan data empiris. Dalam penelitian ini strategi permodelan yang digunakan adalah MG (Modeling Generating). MG digunakan dengan alasan (1) jika tingkat kesesuaian model kurang baik maka model dimodifikasi dan diuji kembali dengan data yang sama, dan (2) proses konstruksi ulang dapat diulang-ulang sampai diperoleh tingkat kesesuaian terbaik. Modifikasi model melalui konstruksi ulang menurut evaluasi terhadap derajat kesesuaian atau Goodness of Fit (GOF) adalah jika perolehan nilai Sesuai Kriteria pada Tabel 1. 
Tabel 1. Kriteria Model Fit

\begin{tabular}{ll}
\hline \multicolumn{1}{c}{ Indikator } & \multicolumn{1}{c}{ Kriteria Fit } \\
\hline Chi-Square & Nilai chi square < \\
& $2 \mathrm{x} \mathrm{df}$ \\
P Value & $>0,05$ \\
Root Mean Square Error of & $0,08-0,1$ \\
Approximation (RMSEA) & \\
Goodness of Fit Index (GFI) & $>0,9$ \\
GFI Adjusted Goodness of & $>0,6$ \\
Fit Index (AGFI) & $<$ independence \\
Model AIC & AIC \\
& $<$ saturated CAIC \\
Model CAIC & $>0,9$ \\
Normed Fit Index (NFI) & $>0,9$ \\
Comparative Fit Index (CFI) & $>0,9$ \\
Incremental Fit Index (IFI & $>0,9$ \\
Relative Fit Index (RFI) & $>0.9$ \\
\hline
\end{tabular}

\section{HASIL DAN PEMBAHASAN}

Berdasarkan hasil analisis data terhadap lima variabel penelitian, yaitu rencana pembelajaran, kompetensi guru, kepemimpinan kepala sekolah, dan kultur sekolah dalam mendukung pembelajaran akuntansi yang mengintegrasikan nilai-nilai anti korupsi sebagai pengembangan karakter diperoleh gambaran sebagai berikut.

Berdasarkan hasil telaah Rencana Pelaksanaan Pembelajaran (RPP) yang mengintegrasikan nilai-nilai anti korupsi, Dengan jumlah sampel yang diteliti sejumlah 165 dokumen RPP dari 20 sekolah yang disusun guru akuntansi, maka data hasil penelitian disajikan pada Tabel 2.

Tabel 2. Kategori kecenderungan rencana pembelajaran

\begin{tabular}{cccc}
\hline Interval & F & F Relatif $(\%)$ & Kategori \\
\hline $44-41$ & 16 & 9,07 & Sangat Baik \\
$37-40$ & 77 & 46,67 & Baik \\
$33-36$ & 49 & 29,70 & Cukup Baik \\
$11-33$ & 23 & 13,94 & Kurang Baik \\
\hline
\end{tabular}

Data Kompetensi guru diperoleh dari hasil pengisisn Instrumen oleh guru untuk Kompetensi Pedagogik dan Profesional dan Siswa untuk Kompetensi Kepribadian dan Sosial, maka data hasil penelitian disajikan pada Tabel 3.
Tabel 3. Kategori kecenderungan Kompetensi Guru

\begin{tabular}{cccc}
\hline Interval & F & F Relatif $(\%)$ & Kategori \\
\hline $35-40$ & 44 & 26,67 & Sangat Baik \\
$32-34$ & 79 & 47,88 & Baik \\
$29-31$ & 27 & 16,36 & Cukup Baik \\
$10-28$ & 15 & 9,09 & Kurang Baik \\
\hline
\end{tabular}

Data kepemimpinan kepala sekolah diperoleh dari hasil pengisisn instrumen oleh guru untuk dapat mengetahui kegiatan pembinaan, kerja sama dan penyediaan fasilitas yang dilakukan kepala sekolah untuk mengembangkan Pembelajaran Akuntansi yang yang mendukung integrasi nilai-nilai anti korupsi, maka data hasil penelitian disajikan pada Tabel 4.

Tabel 4. Kategori Persepsi Guru terhadap Kepemimpinan Kepela Sekolah

\begin{tabular}{cccc}
\hline Interval & F & F Relatif $(\%)$ & Kategori \\
\hline $42-44$ & 52 & 31,52 & Sangat Baik \\
$39-41$ & 84 & 50,91 & Baik \\
$34-38$ & 19 & 11,52 & Cukup Baik \\
$11-33$ & 10 & 6,08 & Kurang Baik \\
\hline
\end{tabular}

Data kultur sekolah diperoleh dari hasil pengisian Instrumen oleh guru pada 20 sekolah tempat guru/responden mengajar untuk dapat mengetahui sikap, kebiasaan dan tata nilai utama terkait dengan nilai-nilai anti korupsi yang diimplementasikan di lingkungan sekolah yang menjadi pedoman bagi warga sekolah untuk mengembangkan karakter anti korupsi, maka data hasil penelitian disajikan pada Tabel 5.

Tabel 5. . Kategori Persepsi Guru terhadap Kultur Sekolah

\begin{tabular}{cccc}
\hline Interval & F & F Relatif $(\%)$ & Kategori \\
\hline $31-32$ & 39 & 23,64 & Sangat Baik \\
$29-30$ & 83 & 50,30 & Baik \\
$26-28$ & 27 & 16,36 & Cukup Baik \\
$8-25$ & 16 & 9,70 & Kurang Baik \\
\hline
\end{tabular}

Pengujian konstruk Pembelajaran Akun-tansi yang mengintegrasikan nilai-nilai anti korupsi sebagai pengembangan karakter dengan variabel Kualitas Rencana Pembelajaran, Kompetensi Guru, Persepsi Guru terhadap Kepemimpinan kepala sekolah dan 
Persepsi Guru terhadap Kultur Sekolah sebagai berikut.

Berdasarkan analisis dapat terlihat hasil semuan loading factor tiap-tiap indikator dari masing-masing variable sudah memenuhi syarat yaitu di atas 0.50 . Semua manifest telah memiliki nilai t hitung > 1,97. Berdasarkan kriteria goodness of fit, nilai loading factor setiap manifes dan nilai $t$ hitung dapat disimpulkan bahwa konstruk yang di susun pada penelitian ini sesuai dengan data empiris dan dapat diterima.contoh hasil pengujian Kompetensi guru dapat dilihat pada Gambar 2.

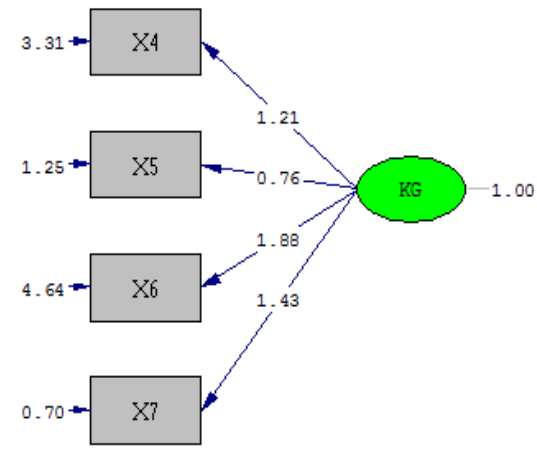

Chi-Square $=61.58, d f=13, \mathrm{p}$-value $=0.10797, \mathrm{RMSEA}=0.035$

Gambar 2. Hasil Pengujian konstruk Kompetensi Guru

Hasil analisis model penuh tahap 1 dari hasil perhitungan LISREL menunjukkan bahwa hubungan variabel Pembelajaran Akuntansi yang mengintegrasikan nilai-nilai anti korupsi sebagai pengembangan karakter (PB) dengan variabel eksogen Kualitas Rencana pembelajaran (RP), Kompetensi Guru (KG), Persepsi Guru terhadap Kepemimpinan kepala sekolah (KP) dan Persepsi Guru terhadap Kultur Sekolah (KT) belum menunjukkan model yang belum fit. Selanjutnya dengan rekomendasi model yang dianjurkan sistem (modification indices) LISREL maka dapat diperoleh model fit setelah dilakukan modifikasi sesuai rekomdasi pada Gambar 3.

Modifikasi yang direkomendasikan adalah variabel persepsi guru terhadap kultur sekolah akan lebih optimal jika mempertimbangkan variabel Kompetensi Guru secara yang mengunakan indikator Pedagogik, hasil modifikasi model yang dilakukan diperoleh nilai chi square 94,85 atau lebih rendah dari model awal, p-value $0.10 \geq 0,05$ dan RMSEA $0,035<0,08$ yang menunjukkan bahwa model yang dibangun fit. Dengan rician hasil uji model fit dapat dilihat pada tabel 6 .

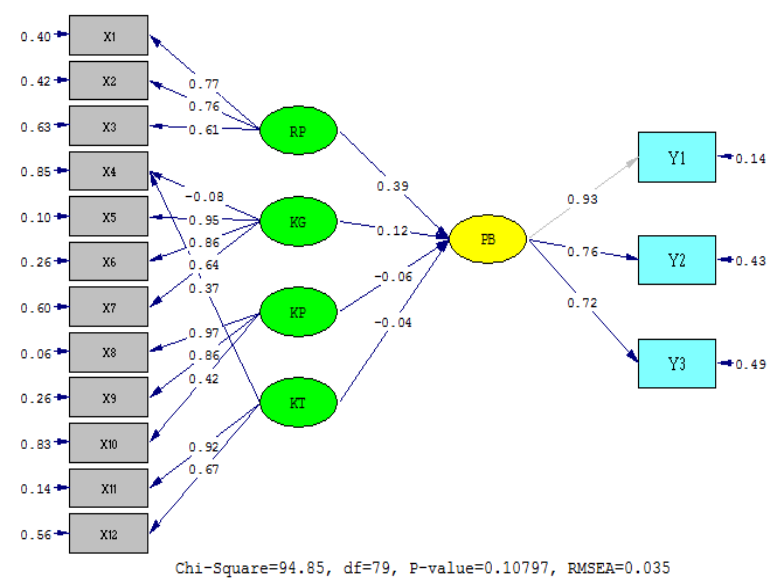

Gambar 3. Hasil Pengujian Model Penuh II

Tabel 6. Hasil Pengujian Model Fit

\begin{tabular}{lc}
\hline \multicolumn{1}{c}{ Indikator Nilai Fit } & Koefisien \\
\hline Chi-Square & 94,85 \\
P Value & 0,10 \\
$\begin{array}{l}\text { Root Mean Square Error of } \\
\text { Approximation (RMSEA) }\end{array}$ & 0,03 \\
Goodness of Fit Index (GFI) & \\
GFI Adjusted Goodness of Fit Index & 0,93 \\
(AGFI) & 0,89 \\
Normed Fit Index (NFI) & \\
Comparative Fit Index (CFI) & 0,94 \\
Incremental Fit Index (IFI & 0,99 \\
Relative Fit Index (RFI) & 0,99 \\
\hline
\end{tabular}

Model hubungan Kualitas Rencana Pembelajaran dengan Pembelajaran Akuntansi yang mengintegrasikan nilai-nilai anti korupsi sebagai pengembangan karakter dari hasil pengujian model fit dapat diketahui:

Rencana Pembelajaran memiliki koefisien jalur dengan Pembelajaran Akuntansi sebesar 0,38 angka tersebut menunjukkan angka positif dan cukup tinggi. Hal ini berarti bahwa jika guru memiliki Rencana Pembelajaran yang baik, maka pembelajaran yang dilaksanakan akan semakin mendukung pengitegrasian nilai-nilai anti korupsi sebagai pengembangan karakter.Hasil analisis untuk mengetahui signifikansi pengaruh dapat dilihat dari nilai nilai p-value sebesar 0,10 . Hal ini berati nilai $p$-value $\geq 0,05$ yang berarti bahwa 
Rencana Pembelajaran memiliki pengaruh yang signifikan terhadap Pembelajaran Akuntansi yang mengintegrasikan nilai-nilai anti korupsi sebagai pengembangan karakter.

Dari hasil diskripsi data penelitian terkait Rencana pembelajaran yang dilakukan Guru menunjukkan distribusi frekuensi Guru yang memiliki kualitas Perencanaan Pembelajaran yang berada dibawah rata-rata hanya $38,20 \%$. Hal ini menunjukkan bahwa pembelajaran yang dilakukan oleh guru sebagian besar $(61,80 \%)$ telah berada diatas rata-rata. Perencanaan pembelajaran merupakan kegiatan awal yang dilakukan oleh guru sebelum melaksanakan pembelajaran, dengan data kuantitatif yang menunjukkan besarnya guru yang telah memiliki kesadaran untuk merancang pembelajaran yang menintegrasika nilai anti korupsi diharapkan membawa pengaruh pada kualitas pembelajaran yang dilakukan.

Perencanaan pembelajaran yang terbentuk dari indikator Metode Pembelajaran, Media dan Bahan Pembelajaran dan Penilaian pembelajaran menunjukkan bahwa semua indikator memiliki kategori yang sangat Baik. Perbandingan antara indikator menunjukkan kontribusi pada Perencanaan pembelajaran adalah Penilaian pembelajaran yang memiliki kategori sangat baik hingga mencapai $75,15 \%$. Hal ini menunjukkan bahwa Metode Pembelajaran bila ditinjau dari komponennya juga memiliki kualitas yang sangat baik, guru memiliki metode yang sangat baik dalam Perencanaan Pembelajaran yang mengintegrasikan nilai-nilai anti korupsi. Media dan Bahan Pembelajaran juga menunjukkan bahwa Guru telah memiliki kemampuan merancanakan strategi yang sangat baik dalam mengintegrasikan nilai-nilai anti korupsi. Hasil pengolahan data kecenderungan menunjukkan bahwa kualitas penilaian pembelajaran yang memiliki kualitas yang kurang baik hanya $7,27 \%$, yang berarti kualitas penilaiam Perencanaan pembelajaran yang dilakukan oleh Guru mayoritas $(92,73 \%)$ memiliki kualitas yang baik dan sangat baik. Dengan adanya kualitas perencanaan pemilaian pembelajaran yang sangat baik dipastikan akan mempengaruhi kualitas dari Kegiatan pembelajaran yang mengintegrasikan nilai-nilai anti korupsi dengan baik. Indikator Strategi pembelajaran menunjukkan kategori yang kurang baik hanya $2,42 \%$, yang berarti $97,58 \%$ memiliki kualitas yang baik dan sangat baik. Dengan strategi pembelajaran yang baik di pastikan berbagai tujuan Pembelajaran Akuntansi untuk mengitegrasikan nilai-nilai anti korupsi dapat tercapai.

Kompetensi Guru memiliki koefisien jalur sebesar 0,12, angka tersebut menunjukkan angka yang cukup. Hal ini berarti bahwa jika guru memiliki kompetensi yang baik, maka pembelajaran akan lebih mendukung pengitegrasian nilai-nilai anti korupsi sebagai pengembangan karakter. Hasil analisis untuk mengetahui signifikansi pengaruh dapat dilihat dari nilai nilai p-value sebesar 0,10 . Hal ini berati nilai $\mathrm{p}$-value $\geq 0,05$. yang berarti bahwa Kompetensi Guru memiliki pengaruh yang signifikan terhadap Pembelajaran Akuntansi yang mengintegrasikan nilai-nilai anti korupsi sebagai pengembangan karakter.

Dari hasil data penelitian terkait Kompentensi Guru menunjukkan distribusi frekuensi guru yang memiliki Kompentensi Guru di bawah rata-rata sebesar 47,88\%. Hal ini menunjukkan bahwa Kompetensi yang dimiliki oleh guru sebagian besar $(52,12 \%)$ telah berada diatas rata-rata. Kompetensi Guru merupakan modal dasar untuk dapat melaksanakan pembelajaran dengan baik, dengan data kuantitatif yang menunjukkan cukup besarnya guru yang telah memiliki kompetensi yang baik memberikan harapaan baik pula kemampuan untuk mengintegrasikan nilai anti korupsi dalam Pembelajaran Akuntansi yang dilakukan.

Kompetensi Guru yang terbentuk dari indikator kompentensi pedagogik, sosial, profesional dan kepribadian diri guru menunjukkan bahwa indikator memiliki kategori yang baik dan sangat baik. Dari perbandingan antara indikator maka yang memberikan kontribusi pada Kompetensi Guru adalah kompetensi pedagogik yang dilakukan guru kategori sangat baik hingga $65,45 \%$. Hal ini menunjukkan bahwa Guru memiliki aktivitas untuk pengembangan pedagogik yang sangat baik, selanjutnya bila ditinjau dari tingkat profesionalisme guru memiliki kategori sangat baik dalam setiap pelaksanaan pembelajaran yang mengintegrasikan nilai-nilai anti korupsi.

Hasil pengolahan data kecenderungan menunjukkan bahwa indikator kompetensi pedagogik dan sosial guru memiliki kualitas yang kurang baik $29,09 \%$, yang berarti Kompetensi Pedagogik dan Sosial yang dimiliki oleh guru mayoritas $(70,91 \%)$ memiliki kuali- 
tas yang baik dan sangat baik. Dengan adanya kualitas Kompetensi Pedagogik dan Sosial guru yang sangat baik dipastikan akan mempengaruhi kualitas dari kegiatan pembelajaran yang mengintegrasikan nilai-nilai anti korupsi dengan baik. Dari indikator Profesinalisme dan Kepribadian menunjukkan kategori yang kurang baik dan tidak baik hanya $6,00 \%$, yang berarti $94,00 \%$ memiliki kualitas yang baik dan sangat baik, dengan yang rata-rata berada kategori Profesinalisme dan Kepribadian yang baik dan sangat baik dipastikan Kompetensi Guru akan menjadi baik dan mendukung Pembelajaran Akuntansi untuk mengitegrasikan nilai-nilai Anti Korupsi dapat tercapai. Kompetensi Guru dalam penelitian juga di tinjau dari penilaian terhadap Kompetensi Kepribadian yang dimiliki oleh guru dalam pembelajaran Akuntansi. Dari hasil analisis data menunjukkan bahwa Kompetensi kepribadian Guru menurut penilaian menunjukkan kategori Sangat Baik dan Baik sebesar 94,00\% sehingga dapat di simpulkan bahwa Kompetensi Guru yang mendukung pengintegrasian nilai-nilai anti korupsi dari dari indikator Kepribadian Guru termasuk dalam kategori sangat baik. Dengan kategori kepribadian yang baik dipastikan guru dapat memiliki modal yang cukup untuk menjadi model/tauladan dalam mengimplementasikan nilai-nilai anti korupsi dalam pelaksanaan pembelajaran maupun di luar kegiatan pembelajaran.

Persepsi Guru terhadap Kepemimpinan Kelapa Sekolah memiliki koefisien jalur sebesar -0,06, angka tersebut menunjukkan hubungan yang rendah. Hal ini berarti bahwa jika guru memiliki presepsi yang baik terhadap kepemimpinan Kepala Sekolah peduli pada nilai-nilai anti korupsi, maka akan menurukan kualitas pembelajaran yang dilakukan oleh guru dalam pengitegrasian nilai-nilai anti korupsi sebagai pengembangan karakter. Hasil analisis untuk mengetahui signifikansi pengaruh dapat dilihat dari nilai $\mathrm{p}$-value sebesar 0,10 . Hal ini berati nilai p-value $\geq 0,05$ yang berarti bahwa Persepsi Guru terhadap Kepemimpinan Kepala Sekolah memiliki pengaruh yang negatif dan signifikan terhadap Pembelajaran Akuntansi yang mengintegrasikan nilai-nilai anti korupsi sebagai pengembangan karakter.

Dari hasil diskripsi data penelitian terkait Persepsi Guru terhadap Kepemimpinan Kepala Sekolah menunjukkan distribusi fre- kuensi tingkat kemampuan Persepsi Guru terhadap kepemimpinan kepala sekolah di bawah rata-rata hanya sebesar $32,00 \%$. Hal ini menunjukkan bahwa tingkat Persepsi Guru terhadap kemampuan kepemimpinan yang dimiliki oleh kepala sekolah sebagian besar $(68,00 \%)$ telah berada diatas rata-rata. Persepsi Guru terhadap Kepemimpinan kepala sekolah merupakan faktor yang menentukan kualitas layanan yang diberikan pada warga sekolah termasuk guru saat melaksanakan pembelajaran, dengan data kuantitatif yang menunjukkan cukup besarnya Kepala Sekolah yang telah memiliki kepemimpinan yang baik dipastikan pula memberikan dampak baik pula pada layanan yang diberikan pada Guru untuk menintegrasika nilai anti korupsi dalam Pembelajaran Akuntansi yang dilakukan.

Persepsi Guru terhadap Kepemimpinan Kepala Sekolah yang terbentuk dari indikator fasilitasi, kerjasama serta pembinaan pada warga sekolah menunjukkan jukkan bahwa indikator memiliki kategori yang sangat baik. Dari perbandingan antara indikator maka yang memberikan kontribusi paling dominan pada Persepsi Guru terhadap Kepemimpinan Kepala Sekolah adalah fasilitasi kepala sekolah pada kategori sangat baik hingga $68,00 \%$. Hal ini menunjukkan bahwa kepala sekolah dengan kemampuan fasilitasi pada warga sekolah yang sangat baik akan dapat memberikan layanan pada warga sekolah untuk dapat mengipmementasikan nilai-nilai anti korupsi. Guru merupakan bagian dari warga sekolah, apabila mendapatkan layanan dan pembinaan yang baik dari kepala sekolah diharapkan dapat melaksanakan pembelajaran akuntansi dengan baik pula.

Hasil pengolahan data kecenderungan menunjukkan bahwa indikator kemampuan fasilitasi kepala sekolah memiliki kualitas yang kurang baik $13,50 \%$, yang berarti kemampuan fasilitasi yang dimiliki oleh kepala sekolah mayoritas $(86,50 \%)$ memiliki kualitas yang baik dan sangat baik. Dengan kemampuan fasilitasi Kepala Sekolah yang sangat baik dipastikan akan mempengaruhi kualitas dari Kegiatan pembelajaran yang mengintegrasikan nilai-nilai anti korupsi dengan baik. Indikator kerjasama penanaman nilai anti korupsi yang dilakukan Kepala Sekolah menunjukkan kategori yang kurang baik dan tidak baik hanya $6,00 \%$, yang berarti $94,00 \%$ memiliki kualitas yang baik dan sangat baik. 
dengan kerjasama penanaman nilai yang ratarata berada kategori baik dan sangat baik di pastikan Guru akan memiliki nilai yang baik saat Pembelajaran Akuntansi untuk mengitegrasikan nilai-nilai anti korupsi. Sedangkan dari indikator pembinaan yang dilakukan Kepala Sekolah menunjukkan kategori yang kurang baik dan tidak baik hanya $9,00 \%$, yang berarti $91,00 \%$ memiliki kualitas yang baik dan sangat baik. Dengan kegiatan pembinaan yang dilakukan kepala sekolah yang rata-rata berada kategori yang baik dan sangat baik dipastikan warga sekolah termasuk guru akan memiliki kebiaasaa baik dan berimbas pada pelaksanaan Pembelajaran Akuntansi untuk mengitegrasikan nilai-nilai anti korupsi yang baik dapat tercapai

Persepsi Guru terhadap Kultur Sekolah memiliki koefisien jalur sebesar -0,04, angka tersebut menunjukkan angka yang rendah. Hal ini berarti bahwa persepsi guru terhadap kultur Sekolah yang baik kurang mendukung dalam pembelajaran yang mengintegrasikan nilai-nilai anti korupsi dilakukan oleh guru sebagai pengembangan karakter. Hasil analisis untuk mengetahui signifikansi pengaruh dapat dilihat dari nilai $p$-value sebesar 0,10 . Hal ini berati nilai $p$-value $\geq 0,05$ yang berarti bahwa persepsi guru terhadap Kultur Sekolah memiliki pengaruh yang negatif dan signifikan terhadap Pembelajaran Akuntansi yang mengintegrasikan nilai-nilai anti korupsi sebagai pengembangan karakter.

Dari hasil diskripsi data penelitian terkait Persepsi Guru terhadap Kultur Sekolah menunjukkan distribusi frekuensi Kultur Sekolah dalam mengitegrasikan nilai-nilai anti korupsi berada dibawah rata - rata hanya sebesar 24,50\%. Hal ini menunjukkan bahwa Persepsi Guru terhadap Kultur Sekolah yang mendukung pengintegrasian nilai-nilai anti korupsi sebagian besar $(68,00 \%)$ telah berada di atas rata-rata. Kultur Sekolah merupakan faktor yang sangat menentukan kualitas pembelajaran, dengan data kuantitatif yang menunjukkan sangat baiknya Kultur sekolah akan memberikan dampak baik pula pada guru untuk mengintegrasikan nilai anti korupsi dalam Pembelajaran Akuntansi yang dilakukan. Hal ini dilarenakan pendidikan nilai akan lebih berhasil jika pembelajaran didukung dengan lingkungan yang telah terkondisi dengan nilai yang di harapkan.
Persepsi Guru terhadap Kultur Sekolah yang terbentuk dari indikator pembiasaan dan sikap anti korupsi dan implementasi tata nilai anti korupsi menunjukkan bahwa indikator memiliki kategori yang sangat baik. Dari perbandingan antara indikator maka yang memberika kontribusi paling dominan pada Kultur Sekolah adalah implementasi tata nilai di sekolah pada kategori sangat baik hingga $80,00 \%$. Hal ini menunjukkan bahwa implementasi tata nilai yang dimiliki sekolah akan mendukung kegiatan pembelajaran akuntansi yang mengiplemementasikan nilai-nilai anti korupsi. Dengan adanya implentasi tata nilai yang baik guru akan dengan mudah mengantarkan siswa untuk membawa kebiasaan tersebut dalam pembelajaran di kelas.

\section{Imlpikasi}

Penelitian ini menemukan bahwa kualitas Rencana Pelaksanaan Pembelajaran (RPP) dan Kompetansi Guru memberikan kontribusi total yang tinggi dan signifikan terhadap terbentuknya proses Pembelajaran Akuntansi terintegrasi dengan nilai-nilai anti korupsi untuk pengembangan karakter. Kualitas Rencana Pelaksanaan Pembelajaran memberikan kontribusi paling tinggi disusul kompetensi guru. Temuan penelitian ini memberikan rekomendasi bahwa penciptaan proses pembelajaran Akuntansi terintegrasi nilai-nilai anti korupsi untuk pengembangan karakter pada peserta didik, haruslah diawali dengan perencanaan pembelajaran serta kompetensi guru yang baik.

Kualitas Perencanaan pembelajaran yang direkomendasikan telah memiliki Metode Pembelajaran yang sesuai dengan karakteristik peserta didik, Media dan Bahan Pembelajaran dengan mengedepankan pemahaman afektif peserta didik dan Penilaian pembelajaran dengan menjadikan nilai nilai karakter anti korupsi sebagai salah satu target keberhasilan dalam pembelajaran.

Temuan dalam penelitian ini menunjukkan bahwa Pengintegrasian nilai-nilai anti korupsi dalam Pembelajaran Akuntansi sebagai pengembangan karakter memerlukan ihtiar yang sinergis, dalam beberapa aspek, mulai dari rencana pembelajaran, kompetensi guru, kepemimpinan kepala sekolah dan kultur sekolah, temuan ini memberikan rekomendasi bahwa upaya pencerahan kepada semua pihak dari seluruh potensi yang ada di sekolah 
mengenai nilai-nilai anti korupsi sebagai pembangunan karakter perlu dilakukan secara terencana, sistematis, dan terpadu dengan melibatkan para ahli pendidikan karakter, dengan didukung oleh para pengambil kebijakan yang terkait.

Pada modifikasi model yang fit ditunjukkan bahwa variabel Perencanaan pembelajaran yang mendukung Pembelajaran Akuntansi terintegrasi nilai-nilai Anti korupsi sebagai pengembangan karakter menunjukkan angka yang paling tinggi sebesar 0,39 sementara itu variabel persepsi guru terhadap Kemepimpinan Kepala sekolah menunjukkan kontribusi yang paling rendah sebesar $-0,06$. Rekomendasi dari temuan ini adalah bahwa dalam proses Pembelajaran Akuntansi yang menintegrasikan nilai-nilai anti korupsi sebagai pengembangan karakter peran perencanaan pembelajaran sangat strategis. Oleh karena itu pembinaan terhadap pengembangan RPP dan kepedulian terhadap nilai-nilai anti korupsi sebagai pengembangan karakter perlu dilakukan secara terencana dan sistematis. Diawali dengan mengubah struktur kognisi guru mengenai pentingnya nilai-nilai anti korupsi sebagai pengembangan karakter sampai kepada upaya mengubah kebiasaan dan perilaku warga sekolah yang mencerminkan kepedulian terhadap nilai-nilai anti korupsi.

Penelitian merekomnendasikan melakukan peninjauan ulang Pembelajaran Akuntansi untuk menuju kepada pembelajaran yang bermuatan nilai-nilai anti korupsi sebagai pengembangan karakter, hal ini memerlukan pembelajaran yang matang dengan memberdayakan seluruh potensi sekolah yang ada. Dalam konteks inilah upaya perbaikan kualitas Pembelajaran Akuntansi yang mengintegrasikan nilai-nilai anti korupsi sebagai pengembangan karakter dilakukan melalui pendekatan manajemen sekolah, yang salah satunya adalah manajemen pembelajaran di sekolah. Dalam konteks manajemen sekolah yang baik perlu disusun sebuah panduan manajemen Pembelajaran Akuntansi yang terintegrasi nilai-nilai anti korupsi sebagai pengembangan karakter berbasis kultur sekolah.

\section{SIMPULAN}

Atas dasar hasil penelitian dan pembahasan dapat disimpulkan hal-hal sebagai berikut.
Sejumlah 46,67\% Rencana Pelaksanaan Pembelajaran (RPP) yang telah mengitegrasikan nilai-nilai anti korupsi sebagai pengembangan karakter siswa menunjukkan kategori baik, 26,67\% siswa memberikan penilaian sangat baik pada Kompetensi guru, $50,91 \%$ guru memiliki Persepsi baik terhadap Kepemimpinan kepala sekolah, 50,30\% guru memiliki Persepsi baik terhadap kultur sekolah yang mengintegrasikan nilai-nilai anti korupsi menunjukkan kategori, 46,06\% guru telah mengintegrasikan nilai-nilai anti korupsi dalam pembelajaran Akuntansi dengan baik.

Hasil pengujian model penuh dengan SEM diperoleh model fit, hal ini menunjukkan adanya pengaruh yang signifikan dari berbagai faktor terhadap pembelajaran Akuntansi yang mengintegrasikan nilai-nilai anti korupsi

Kualitas Rencana Pembelajaran adalah faktor yang paling berpengaruh terhadap kualitas pembelajaran akuntansi yang mengintegrasikan nilai-nilai anti korupsi sebagai pengembangan karakter siswa dengan koefisien jalur 0,39 .

Dalam Pengintegrasian nilai-nilai anti korupsi dalam Pembelajaran Akuntansi sebagai pengembangan karakter memerlukan ihtiar yang sinergis, dalam beberapa aspek.oleh sebab itu penelitian ini memberikan saran sebagai berikut. Pertama, Sekolah perlu melakukan pembinaan secara berkelanjutan pada guru untuk menyusun Rencana Pelaksanaan Pembelajaran (RPP) terintegrasi nilai-nilai anti korupsi sebagai pengembangan karakter siswa dengan pemilihan pendekatan/metode/strategi pembelajaran yang relevan dengan indikator, tujuan pembelajaran, dan materi pembelajaran; Kedua, Sekolah mengalokasikan/manfasilitasi pendanaan yang cukup untuk berbagai kegiatan (workshop, pelatihan, seminar ,studi lanjut dll ) guru dalam rangkan meningkatkan kompentesi guru.

\section{DAFTAR PUSTAKA}

Cronbach, L. J. (1977). Educational psychology (3rd ed.). New York: Harcourt Brace Jovanovich, Inc.

Depdiknas. Undang-Undang Nomor 20 Tahun 2003 tentang Sistem Pendidikan Nasional (2003). Jakarta.

Dharma, A. (2003). Manajemen supervisi: 
petunjuk praktis bagi para supervisor. Jakarta: Raja Grafindo Persada.

Durkheim, E. (1961). Moral education. New York: The Free Press Of Glencoe.

Kartowagiran, B. (2008). Validasi dimensionalitas perangkat tes ujian akhir nasional SMP mata pelajaran Matematika 2003-2006. Jurnal Penelitian Dan Evaluasi Pendidikan, 12(2). Retrieved from https://journal.uny.ac.id/index.php/jpep/a rticle/view/1426

Kemp, J. E. (1994). Proses perancangan pengajaran (Terjemahan Asril Marjohan). Bandung: ITB Press.

Komisi Pemberantasan Korupsi. (2014). Perkembangan tindak pidana korupsi di Indonesia. Retrieved April 6, 2014, from www.acch.kpk.go.id

Kusnandar. (2008). Guru profesional implementasi kurikulum tingkat satuan pendidikan (KTSP) dan persiapan menghadapi sertifikasi guru. Jakarta: Raja Grafindo Persada.

Lickona, T. (2003). My thoughts about national character. Ithaca and London: Cornell University Press.

Menteri Pendidikan Nasional. Peraturan pemerintah republik indonesia nomor 19 tahun 2005 tentang standar nasional pendidikan (2005).

Menteri Pendidikan Nasional. Peraturan menteri pendidikan nasional nomor 22 tahun 2006 standar isi (2006).

Mulyasa. (2002). Menjadi guru profesional menciptakan pembelajaran kreatif dan menyenangkan. Bandung: Remaja Rosda Karya.

Poerwadarminta. (1999). Kamus umum bahasa indonesia. Jakarta: Balai Pustaka.

Presiden Republik Indonesia. Inpres no 1 tahun 2010 tentang percepatan pelaksanaan prioritas pembangunan nasional. (2010).

Purwanto, N. (2003). Psikologi pendidikan. Bandung: PT. Remaja Rosdakarya.

Satmoko. (1983). Pengaruh bimbingan kelompok pada perkembangan kepribadian Pancasila murid-murid sekolah lanjutan. Disertasi. Fakultas Pasca Sarjana Institut Keguruan dan Ilmu Pendidikan Jakarta.

Suhertian. (1990). Paradigma pendidikan universal di era modern dan postmodern. yogyakarta: IRCiSoD.

Sunarto. (2000). Analisis wacana, ideologi jender media anak-anak. Semarang: Mimbar. 